Reprod. Nutr. Dévelop., 1982, 22 (2), 355-362.

\title{
Thyroxine, triiodothyronine and iodide in different breeds of newborn calves
}

\author{
Marie-Jeanne DAVICCO, E. VIGOUROUX (*), C. DARDILLAT, J.-P. BARLET (i) \\ I.N.R.A., Theix, 63110 Beaumont, France. \\ $\left(^{*}\right)$ Laboratoire de Physiologie Comparée, Université P. et M. Curie, \\ 4, place Jussieu, 75230 Paris Cedex 05.
}

Summary. Plasma thyroxine $\left(T_{4}\right)$, triiodothyronine $\left(T_{3}\right)$ and iodide levels were measured from birth until 30 days of age in 17 Holstein $\times$ Friesian (HF), 7 Salers and 7 Charolais calves born at term. The response of plasma $T_{4}$ and $T_{3}$ levels to bovine thyrotropin (TSH) injection was also compared in two groups of $9 \mathrm{HF}$ calves 3 hrs and 21 days, respectively, after birth.

In the HF calves, plasma $T_{4}$ and $T_{3}$ levels increased from birth to $6 \mathrm{hrs}$ (when the rectal temperature of these calves decreased slight|yl, then diminished until day 7 and remained stable until 30 days of age. In Salers calves, changes in the plasma $T_{4}$ and $T_{3}$ levels were not different from those observed in HF animals. However, in Charolais calves, there was no significant increase in plasma $T_{4}$ and $T_{3}$ levels after birth. Twelve and $24 \mathrm{hrs}$ after birth, the plasma iodothyronine levels measured in these animals were lower than in HF calves. In Salers and Charolais calves a positive linear relationship was demonstrated between plasma $T_{4}$ (or $T_{3}$ ) levels at birth and the birth weight. In the three groups of calves, plasma iodide levels decreased from birth until 10 days of age, then remained stable until the end of the first neonatal month.

Intravenous injection of the same dose of bovine TSH $(5 \mathrm{mU} / \mathrm{kg}$ of body weight) induced a rise in the plasma $T_{4}$ and $T_{3}$ levels which was significantly more intense in 21-day old calves than in 3-hr old calves.

\section{Introduction.}

The function of the mammalian thyroid gland during the perinatal period has received much attention during the past few years (Geloso, 1967 ; Thorburn and Hopkins, 1973 ; Vigouroux, 1976 ; Fisher et al., 1977). However, to our knowledge there are very few sequential studies of the plasma iodothyronine level in newborn calves (Nathanielsz, 1969 ; Kahl, Wrenn and Bitman, 1977 ; Cabello, 1980). Moreover, these studies were conducted on only a few animals and provide no precise information on putative changes occurring immediately after birth in calves and lambs (Fisher et al., 1977; Davicco, Vigouroux and Barlet, 1980). The aim of this work was (i) to follow postnatal changes in plasma

(1) Address correspondence to : J.-P. Barlet, I.N.R.A., Theix, 63110 Beaumont, France. 
iodothyronine and iodide levels in calves of different breeds, (ii) to investigate the possible influence of birth weight on these parameters and (iii) to observe the response of newborn calves to thyrotropin.

\section{Material and methods.}

We used 35 Holstein $\times$ Friesian (HF) calves born on days $278-280$ of gestation (birth weight : $38 \pm 1 \mathrm{~kg}$; mean \pm SEM), 7 Salers calves born on days 278280 of gestation (birth weight : $40 \pm 2 \mathrm{~kg}$ ) and 7 Charolais calves born on days $285-286$ of gestation (birth weight : $43 \pm 1.5 \mathrm{~kg}$ ). The normal length of gestation in our herd is $278 \pm 2$ days for Holstein $\times$ Friesian, $281 \pm 2$ days for Salers and $284 \pm 3$ days for Charolais cows.

At birth the HF calves were immediately housed in open boxes outside and fed maternal colostrum twice a day during the first neonatal week. They then received a commercial milk replacer ad libitum during the first neonatal month. The other calves from suckling beef cows were left with their dams and suckled colostrum or milk ad libitum.

To observe the possible influence of age on the response of calf thyroid to thyrotropin, $18 \mathrm{HF}$ calves were injected with purified bovine thyrotropin (bTSH ; NIAMDD-bTSH-9; $21.1 \mathrm{lU} / \mathrm{mg}$ ) either at $3 \mathrm{hrs}$ (9 calves) or at 21 days (9 calves) after birth. The bTSH was dissolved in physiological saline containing $0.5 \mathrm{p} .100$ bovine serum albumin and quickly injected $(5 \mathrm{ImU} / \mathrm{kg}$ of body weight) into the left jugular vein of each calf. Control calves of the same age (7 in each group) were injected with the same volume $(0.2 \mathrm{ml} / \mathrm{kg}$ of body weight) of solvent alone. The calves were chosen according to their birth time so that all injections could be given at 9 a.m.

Serial blood samples $(3 \mathrm{ml})$ were collected from all the calves by puncture of the right jugular vein. Rectal temperature was also taken in HF calves at the time of the first blood collection after birth. After centrifugation, the plasma was frozen until assay.

Total plasma $T_{4}$ and $T_{3}$ concentrations were measured by radioimmunoassay using $T_{3}$ (Trik) and total $T_{4}$ (Tetrak) radioimmunoassay kits from the French Atomic Energy Commission. In our experimental conditions, $T_{4}$ assay reproducibility was $2 \mathrm{p} .100$ and its sensitivity was $1 \mathrm{ng} / \mathrm{ml}$ of plasma; $T_{3}$ assay reproducibility was 3 p. 100 and its sensitivity was $15 \mathrm{pg} / \mathrm{ml}$ of plasma. No significant interference with other iodothyronines or iodotyrosines was observed in any of the assays.

Plasma iodide levels were estimated by a previously described method (Vigouroux, 1976 ; Davicco, Vigouroux and Barlet, 1980).

The results were expressed as the mean \pm SEM. Student's t-test was used for statistical comparison.

\section{Results.}

The plasma $\mathrm{T}_{4}$ levels $(\mu \mathrm{g} / \mathrm{dl})$ in the $17 \mathrm{HF}$ calves increased from $14.7 \pm 1$ at 0 hrs to $18.2 \pm 2$ at 6 hrs $(P<0.01)$, then decreased to $13.5 \pm 0.9$ at 24 hrs 
$(P<0.01)$, to $7.2 \pm 0.8$ at 7 days $(P<0.01)$, and finally remained stable until 30 days $(7.3 \pm 0.4)$ (fig. 1$)$.

The plasma $T_{3}$ levels $(\mathrm{ng} / \mathrm{dl})$ in these animals increased from $288 \pm 20$ at birth to $466 \pm 41$ at 6 hrs $(P<0.01)$. They were $351 \pm 55$ at $24 \mathrm{hrs}$ and decreased to $200 \pm 36$ at 7 days $(P<0.01)$, then remained stable until 30 days $(247 \pm 27)$ (fig. 1).
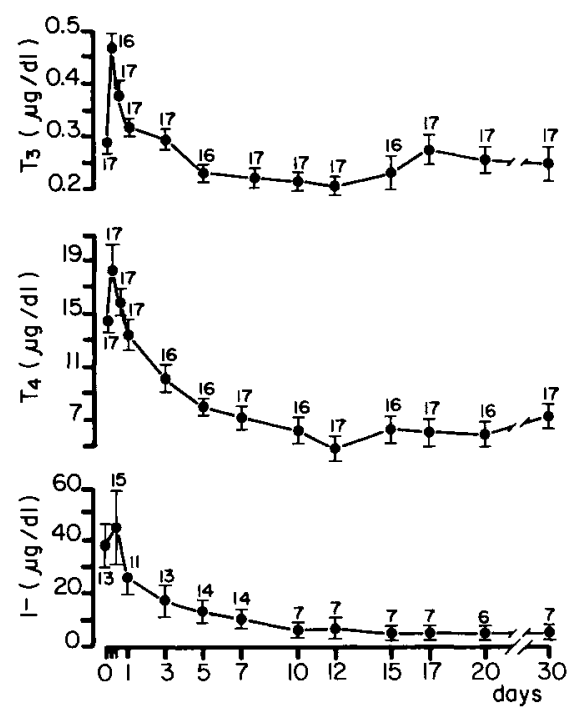

FIG. 1. - Plasma triiodothyronine $\left(T_{3}\right)$, thyroxine $\left(T_{4}\right)$ and iodide $\left(1^{-}\right)$levels in Holstein $\times$Friesian calves during the first neonatal month (mean \pm SEM). The number of assays in shown above each bar.

In the 7 Salers calves (table 1), the plasma $T_{4}$ levels never differed from those measured in HF calves ; however, the plasma $T_{3}$ levels in the Salers calves never varied significantly between birth $(270 \pm 17)$ and 30 days $(263 \pm 3)$. In the 7 Charolais calves, plasma $\mathrm{T}_{4}$ levels did not vary significantly between birth $(13.8 \pm 2.7)$ and 12 hrs $(13.6 \pm 2.3)$, then they decreased until 10 days $(4.6 \pm 0.9 ; \mathrm{P}<0.01)$ and remained stable until 30 days $(5 \pm 1)$. Plasma $T_{3}$ levels measured in these Charolais calves at birth $(221 \pm 27), 12 \mathrm{hrs}(290 \pm 21)$, $24 \mathrm{hrs}(259 \pm 9)$ and 30 days $(179 \pm 22)$ were lower $(P<0.01)$ than those measured in HF calves at the same respective times (fig. 1). The $T_{3}$ surge at $12 \mathrm{hrs}$ was particularly lower in Salers and Charolais calves than in HF animals.

Plasma iodide levels measured between birth and 30 days were similar in all groups of calves. In HF animals plasma iodide levels decreased from birth $(0.37 \pm 0.08 \mu \mathrm{g} / \mathrm{ml})$ until 10 days $(0.06 \pm 0.02 \mu \mathrm{g} / \mathrm{ml} ; \mathrm{P}<0.01)$, then rernained stable until 30 days $(0.05 \pm 0.01 \mu \mathrm{g} / \mathrm{ml}$ ) (fig. 1$)$.

No significant relationship could be found in these animals between plasma iodide levels and birth weight or between plasma $T_{4}$ or $T_{3}$ levels and birth weight. However, in the 14 Salers and Charolais calves a positive linear relationship was demonstrated between birth weight $(x)$ and plasma $T_{4}$ level $(y)$ at $0 \mathrm{hrs}$ $(y=0.48 x-3.5 ; \quad r=0.69 ; P<0.01)$ and $12 \mathrm{hrs}(y=0.6 x-11$; $r=0.66 ; P<0.01)$, and between birth weight $(x)$ and plasma $T_{3}$ level $(y)$ at 12 hrs $(y=5.54 x+54 ; r=0.68 ; P<0.01)$. In the 9 calves injected with 


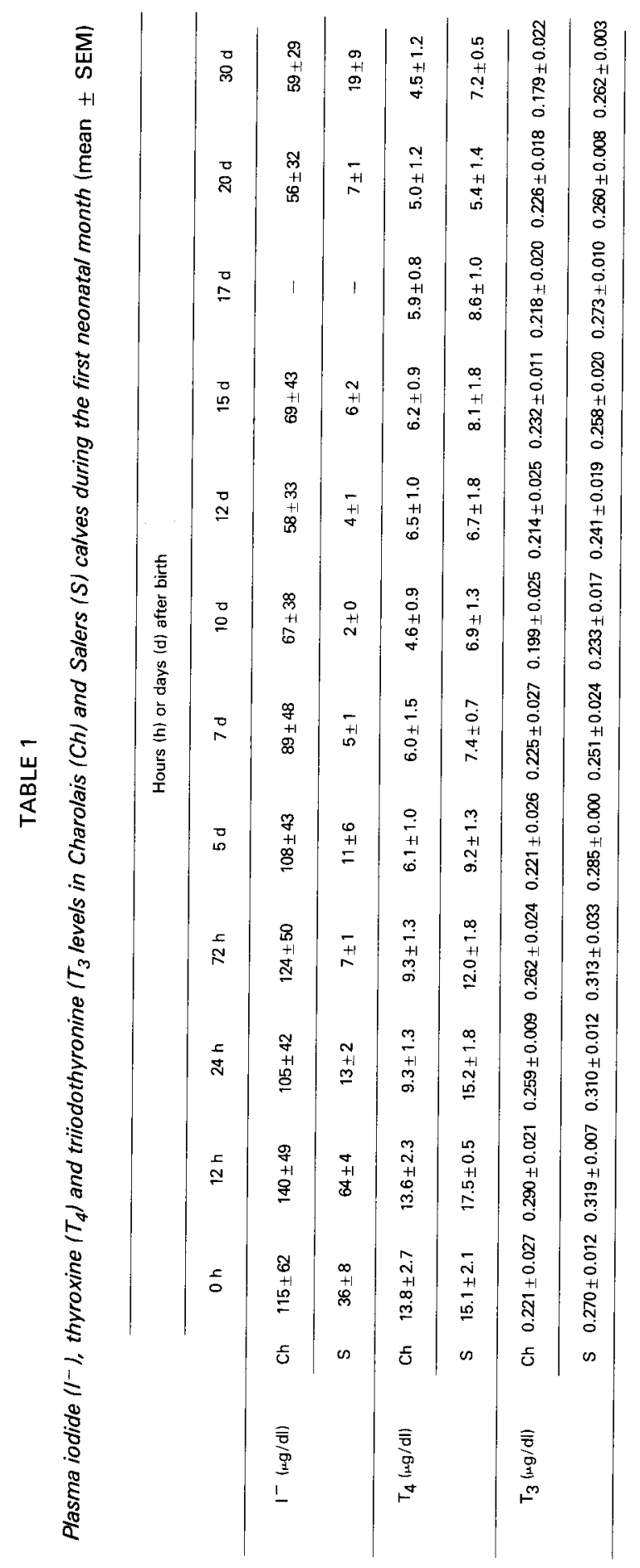


bTSH $3 \mathrm{hrs}$ after birth, plasma $\mathrm{T}_{4}$ increased from $11.3 \pm 1.5 \mu \mathrm{g} / \mathrm{dl}$ at the time of injection ot a maximum of $16.7 \pm 1.1 \mu \mathrm{g} / \mathrm{dll}(\mathrm{P}<0.05) 3 \mathrm{hrs}$ later. In these 9 animals, plasma $T_{3}$ levels did not vary significantly $(486 \pm 28 \mathrm{ng} / \mathrm{dl})$ at the time of injection ; maximum $90 \mathrm{~min}$ later : $513 \pm 42 \mathrm{ng} / \mathrm{dl}$ ). In the 9 calves injected with bTSH at 21 days, plasma $T_{4}$ levels increased from $4.9 \pm 0.6 \mu \mathrm{g} / \mathrm{dl}$ at the time of injection to $9.7 \pm 0.7 \mu \mathrm{g} / \mathrm{dl} 3 \mathrm{hrs}$ later $(P<0.01) ; T_{3}$ levels increased from $123 \pm 7 \mathrm{ng} / \mathrm{dl}$ at the time of injection to $195 \pm 32 \mathrm{ng} / \mathrm{dl} 90 \mathrm{~min}$ later $(P<0.01)$. Plasma $T_{4}$ and $T_{3}$ levels did not vary significantly in control calves (fig. 2).

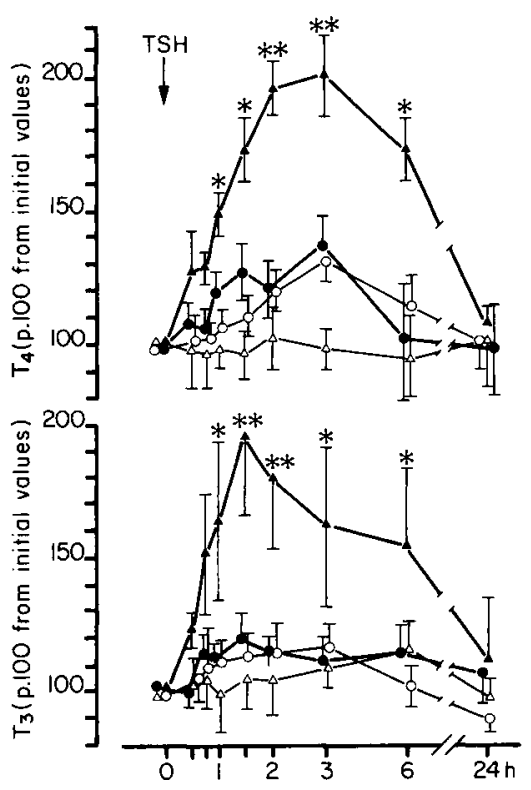

FIG. 2. - Plasma thyroxine $\left(\mathrm{T}_{4}\right)$ and triiodothyronine $\left(\mathrm{T}_{3}\right)$ levels in nine 3-hour-old ( $-\bullet ; 0$ 7 control animals) and nine 21-day-old ( $\mathbf{\Delta}-\mathbf{\Delta}$; $\triangle-\triangle 7$ control animals) calves following the injection of bovine thyrotropin (TSH ; $5 \mathrm{mU} / \mathrm{kg}$ body weight) (mean \pm SEM). ${ }^{*} \mathrm{P}<0.01$; comparison with control animals of the same group.

\section{Discussion.}

Plasma iodide levels have already been measured in newborn infants (Malvaux, Beckers and De Visscher, 1965), rats (Vigouroux, 1976) and lambs (Davicco, Vigouroux and Barlet, 1980); these concentrations increased after suckling in newborn rats and lambs. In our calves, plasma iodide levels decreased from birth until day 10 (fig. 1). This profile of the plasma iodide levels does not seem to be related to calf milk consumption since it was similar in the three groups of animals in which HF calves (from dairy cows) were fed only twice daily and Salers and Charolais (from suckling beef cows) suckled ad libitum. At the end of gestation in the bovine species, maternal iodine passes readily to the foetus (Miller et al., 1967). At birth plasma iodine concentrations are much higher in the calves $(32.8 \mu \mathrm{g} / \mathrm{dl})$ than in their dams $(4 \mu \mathrm{g} / \mathrm{dl})$, then during the first 6 neonatal days, there is a marked decrease in both total and protein-bound iodine in the calf 
plasma, suggesting a high rate of fecal as well as urinary iodine excretion during that period (Miller et al., 1967). This might explain the similar decrease in plasma iodide levels observed in the three groups of calves in the present study (fig. 1 ; table 1).

The profile of plasma $T_{4}$ and $T_{3}$ levels in the first neonatal hours is similar to that already described in newborn lambs (Nathanielsz, Silver and Comline, 1973). In 32 healthy Friesian or HF calves plasma hormonal iodine levels measured at birth and $48 \mathrm{hrs}$ later were lower than those simultaneously measured in calves which suffered from diarrhea but survived (Cabello, 1980). The calves in our experiment were in apparently good condition ; mean daily weight gain during the first neonatal month was $994 \pm 87 \mathrm{~g}, 1037 \pm 104 \mathrm{~g}$ and $1138 \pm 209 \mathrm{~g}$ for HF, Salers and Charolais calves, respectively. In newborn lambs and human infants, the neonatal TSH surge inducing the rise in plasma iodothyronine levels appears to be a result of extrauterine cooling ; these $\mathrm{TSH}$ and iodothyronine surges can be prevented by delivering the newborn into a $37-39{ }^{\circ} \mathrm{C}$ water-bath (Fisher et al., 1977). Although we could not establish any relationship between external temperature and plasma thyroid hormone levels in our animals during the first 6 neonatal hours, the rectal temperature of the $17 \mathrm{HF}$ calves decreased from $38.8 \pm 0.1{ }^{\circ} \mathrm{C}$ to $38.2 \pm 0.2{ }^{\circ} \mathrm{C}(P<0.05)$, while the plasma $T_{4}$ and $T_{3}$ levels increased significantly (fig. 1).

Twelve hours after birth, plasma $T_{4}$ and $T_{3}$ levels were higher in HF (dairy) than in Charolais (beef) calves (fig. 1 ; table 1). Similarly, during the first 89 neonatal days, the total $T_{4}$ and the free $T_{4}$ index were occasionally higher in the plasma of Friesian (dairy) bull calves than in that of Hereford (beef) calves (Hart et al., 1979). In beef calves as in newborn lambs (Davicco, Vigouroux and Barlet, 1980), a positive linear relationship was observed between birth weight and plasma thyroid hormone levels at birth. We could not demonstrate such relationships in HF calves. Similarly, Strbàk, Tomsik and Hlozanek (1976) found no correlation between thyroid hormone level in the foetal plasma and foetal body weight in Czech redwhite cows during the last month of gestation.

Using a specific radioimmunoassay for bovine TSH, the normal TSH level measured in Hereford cows was $2.5 \mathrm{ng} / \mathrm{ml}(5 \mathrm{mU}$ of bovine TSH/100 ml; Hopkins, Wallace and Thorburn, 1975). We can thus assume that we used a physiological dose $(5 \mathrm{mU} / \mathrm{kg}$ of body weight) of bovine TSH in our calves. The injection of bovine TSH (200 mU/ kg of body weight) in four 12-hour old Jersey calves induced a significant rise in plasma hormone iodine levels, which was less intense than that measured in 3 of the same animals after the same TSH dose injected at 21 days of age (Cabello and Michel, 1977). The dose of TSH which we used (5 mU/kg of body weight) induced a significantly more intense rise in plasma $T_{4}$ and $T_{3}$ levels in 21-day old calves than in 3-hour old calves (fig. 2). The blood iodothyronine level represents the ratio of iodothyronine secretion to metabolic clearance rate. A sudden rise in peripheral $T_{4}$ utilization about 18-21 days after birth has been demonstrated in Jersey calves (Nathanielsz, 1969). Thus, the greater increase in plasma $\mathrm{T}_{4}$ levels after TSH injection in the 21-day old calves probably resulted from a more intense $T_{4}$ release by the thyroid gland. This would also induce a greater rise in plasma $T_{3}$ levels since in newborn lambs, as in 
adult sheep, 56 p. 100 of the $\mathrm{T}_{3}$ produced is derived from the $\beta$-ring monodeiodination of $T_{4}$ (Klein, Oddie and Fisher, 1980). THere are several possible reasons for the apparently greater TSH sensitivity of the 21-day old calf thyroid. Firstly, after the TSH surge at birth (Fisher et al., 1977), the occupation of the thyroidal TSH receptors is probably more intense in 3-hour-old calves than in older animals. Secondly, the high levels of circulating $T_{3}$ and $T_{4}$ in the youngest calves (fig. 1 ; table 1) probably decreased thyroid sensitivity to TSH stimulation (Sterling and Lazarus, 1977). Increased free thyroidal TSH receptors associated with decreased plasma $\mathrm{T}_{3}, \mathrm{~T}_{4}$ levels and endogenous TSH induced a greater exogenous TSH sensitivity in the oldest calves. Similarly, thyroid gland TSH sensitivity appears to increase throughout neonatal life in lambs (Klein and Fisher, 1980).

In conclusion, in newborn calves the thyroid function was characterized by a transient increase in plasma thyroxine and triiodothyronine levels during the first 6 neonatal hours, while at the same time the rectal temperature decreased slightly but significantly. Plasma $T_{4}$ and $T_{3}$ levels then decreased during the first neonatal week and remained stable until day 30 . The intravenous injection of a physiological dose of bovine TSH induced a rise in the plasma iodothyronine levels of 3-week old, but not of 3-hour old, calves.

Reçu en juillet 1981.

Accepté en octobre 1981.

Acknowledgements. - This work was supported by a grant from the INRA (" Recherches Programmées sur la Périnatalité $»)$. The calves used in this study were supplied by the "Laboratoire de Production Laitière" and the "Laboratoire de Production de Viande". The gift of bovine TSH by the NIAMDD is gratefully acknowledged.

Résumé. La thyroxinémie $\left(T_{4}\right)$, la triiodothyroninémie $\left(T_{3}\right)$ et l'iodurémie ont été mesurées depuis la naissance jusqu'à l'âge de 30 jours chez 17 veaux Holstein $\times$ Frisons (HF), 7 veaux Salers et 7 veaux Charolais, nés à terme. La réponse de $T_{3}$ et $T_{4}$ à une injection d'hormone thyréotrope bovine (TSH) a aussi été mesurée chez 2 groupes de 9 veaux HF, âgés respectivement de $3 \mathrm{~h}$ et de 21 jours.

Chez les veaux $H F, T_{3}$ et $T_{4}$ s'élevaient depuis la naissance jusqu'à l'âge de $6 \mathrm{~h}$ lalors que la température rectale des animaux s'abaissait légèrement), puis diminuaient jusqu'au $7^{e}$ jour, et restaient ensuite stables jusqu'à 30 jours. Chez les veaux Salers les variations de $T_{3}$ et $T_{4}$ n'étaient pas différentes de celles observées chez les animaux HF. Chez les veaux Charolais nous $n$ 'avons pas pu mettre en évidence d'augmentation significative de $T_{3}$ et $T_{4}$ après la naissance, et 12 et $24 \mathrm{~h}$ après celle-ci les taux plasmatiques des iodothyronines mesurés chez ces veaux Charolais étaient inférieurs à ceux trouvés chez les Frisons aux mêmes âges. Chez les Salers et les Charolais il existait une corrélation positive entre $T_{3}$ (ou $\mathrm{T}_{4}$ ) à la naissance et poids de naissance, corrélation que nous n'avons pas retrouvée chez les veaux HF. Dans les 3 lots d'animaux l'iodurémie diminuait entre la naissance et 10 jours, puis restait stable jusqu'à 30 jours.

L'injection intraveineuse d'une même dose de TSH (5 mU par kg de poids vif) induisait une élévation de $T_{3}$ et $T_{4}$ plus intense chez les veaux de 21 jours que chez ceux âgés de $3 \mathrm{~h}$. 


\section{References}

CABELLO G., 1980. Relationships between thyroid function and pathology of the newborn calf. Biol. Neonate, 37, 80-87.

CABELLO G., MICHEL M. C., 1977. Evolution en fonction de l'âge de la réponse de l'iodémie hormonale du jeune veau à une injection de thyréostimuline. C. R. Acad. Sci., Paris, sér. D, 248, 2527-2530.

DAVICCO M. J., VIGOUROUX E., BARLET J. P., 1980. Relationships between birthweight and plasma thyroxine, triiodothyronine and iodide concentrations in lambs. J. Develop. Physiol., 2, 53-58.

FISHER D. A., DUSSAULT J. H., SACK J., CHOPRA I. J., 1977. Ontogenesis of hypothalamicpituitary-thyroid function and metabolism in man, sheep and rat. Recent Progr. Horm. Res., 33, 59-116.

GELOSO J. P., 1967. Fonctionnement de la thyroïde et corrélations thyréohypophysaires chez le fœtus de rat. Ann. Endocr., 28, 5-79.

HART I. C., BINES J. A., ROY J. H. B., MORANT S. V., 1979. Plasma thyroxine and free thyroxine index in high and low-yielding cattle and in calves of different breeds. $J$. Endocr., 80, 52P-53P.

HOPKINS P. S., WALLACE A. L. C., THORBURN G. D., 1975. Thyrotrophin concentrations in the plasma of cattle, sheep and foetal lambs as measured by radioimmunoassay. J. Endocr., 64. 371-387.

KAHL S., WRENN T. R., BITMAN J., 1977. Plasma triiodothyronine and thyroxine in young growing calves. J. Endocr., 73, 397-398.

KLEIN A. H., FISHER D. A., 1980. Thyrotropin-releasing hormone-stimulated pituitary and thyroid gland responsiveness and 3,5,3'-triiodothyronine suppression in fetal and neonatal lambs. Endocrinology, 106, 697-701.

KLEIN A. H., ODDIE T. H., FISHER D. A., 1980. lodothyronine kinetic studies in the newborn lamb. J. Develop. Physiol., 2, 29-35.

MALVAUX P., BECKERS C., DE VISSCHER M., 1965. Dynamic studies on the inorganic iodine compartment and its exchange during adolescence. J. clin. Endocr. Metab., 25, 817-822.

MILLER J. K., SWANSON E. W., ASCHBACHER P. W., CRAGLE R. G., 1967. lodine transfer and concentration in the prepartum cow, fetus and neonatal calf. J. Dairy Sci., 50, 1301-1305.

NATHANIELSZ P. W., 1969. Peripheral utilization of thyroxine by the young growing calf. J. Physiol. London, 204, 43P-45P.

NATHANIELSZ P. W., SILVER M., COMLINE S., 1973. Plasma triiodothyronine concentration in the foetal and newborn lamb. J. Endocr., 58, 683-684.

STERLING K., LAZARUS J. H., 1977. The thyroid and its control. Ann. Rev. Physiol., 39, 349-371.

STRBȦK V., TOMSIK F., HLOZANEK I., 1976. Thyroid hormone in serum of fetal calf and pregnant cow during the last trimester of pregnancy. Experientia, 32, 1215-1216.

THORBURN G. D., HOPKINS P. S., 1973. Thyroid function in the foetal lamb, 488-507. In COMLINE R. S., CROSS K. W., DAVES G. S. \& NATHANIELSZ P. W., Foetal and neonatal Physiology, Cambridge Univ. Press, London.

VIGOUROUX E., 1976. Dynamic study of post-natal thyroid function in the rat. Acta endocrinol. $(K b h), 83,752-762$. 